\title{
Using vouchers to privatize an economy: the Czech and Slovak case
}

\section{Jan Svejnar and Miroslav Singer}

\author{
CERGE-EI \\ Charles University \\ Politických vězñu 7 \\ P.O. Box 882 \\ 11121 Prague 1 \\ Czech Republic \\ Tel: (422) 268901
}

\section{Introduction}

The 1992 Czechoslovak privatization of state property has been widely heralded as one of the most impressive accomplishments in the economic transformation of the formerly communist economies. Before separating into two countries on January 1, 1993, Czechoslovakia undertook rapid large-scale privatization of state enterprises. A key element of the process was voucher privatization - the almost free distribution of vouchers to citizens who in turn used the vouchers to bid for shares in state enterprises. The design and implementation of the Czechoslovak voucher scheme has sparked a lively debate among academics and policy-makers in many countries. A small percentage of Russian enterprises has already been privatized through a different voucher scheme and other systems may be introduced in other transforming economies as well.

While voucher privatization has an obvious popular appeal, many transitional economies have so far avoided it because of the perceived uncertainty about the process and its outcome. The iterative scheme used in Czechoslovakia is a relatively cumbersome procedure which has never been tried on a large scale before. The non-existence of supporting institutions and the inexperience of the participating citizens and officials also make it hard to assess its feasibility. The results of the 1992 Czechoslovak experiment are the first ones to reveal the behaviour of individual citizens, the investment privatization funds (IPFs) and the government authorities in the process of voucher privatization. As such, they are of significant academic as well as of policy interest. ${ }^{1}$

In this paper we use data on the 1,491 enterprises which participated in the first wave of Czechoslovak voucher privatization to undertake an empirical analysis of (a) the demand of individual voucher holders and the IPFs for enterprise shares in the five rounds of bidding and (b) the price-setting behaviour of the authorities in these rounds. Since the data set contains all the firm-specific as well as more aggregate variables that were publicly available to the bidding individuals and IPFs, we can assess the importance of the various indicators for the bidding behaviour. Similarly, using the data that were available to the authorities, we are able to trace their complex price-setting behaviour and show that it can be very closely approximated by a relatively simple functional form. 
The paper is structured as follows. In Section 2 we identify the main elements of the Czechoslovak privatization programme, with an emphasis on the voucher scheme. In Section 3 we describe the data set and in Section 4 we present the econometric model. In Section 5 we discuss the results, while in Section 6 we draw the conclusions.

\section{The Czechoslovak privatization programme}

As in many other Central and East European countries, the privatization of state property in Czechoslovakia was divided into two parts, covering small and large units, respectively. The privatization of small and medium sized units commenced in late 1990 and has proceeded very successfully since then. It resulted in the privatization of tens of thousands of small establishments and a significant revenue inflow for the government. ${ }^{2}$

\subsection{Privatization of large firms}

In 1991 the Czechoslovak government earmarked approximately six thousand large enterprises for privatization. About 4,400 of these were in the Czech Republic and 1,600 in Slovakia. The privatization process was divided into two waves, with each wave consisting of several rounds of bidding in the case of firms that entered voucher privatization. As can be seen from Table 1, the first wave, which took place in 1992, involved over three thousand enterprises, thus covering about one-half of all firms slated for privatization. The shares of firms that entered voucher privatization were distributed in five rounds of bidding. In view of the partition of Czechoslovakia into two independent republies on January 1, 1993, the second wave was launched as originally scheduled in late 1993 in the Czech Republic but not in Slovakia.

Within the first wave, which is the focus of this paper, enterprises were privatized on the basis of privatization projects which were selected from a number of competing proposals by the Czech and Slovak Ministries of Privatization and by the Federal Ministry of Finance. The projects could be submitted by any domestic or foreign individual or group and they could propose any one or a combination of permissible privatization methods, including direct sale to an individual or a private domestic or foreign firm, sealed bids, public auction, and distribution of shares to citizens at large through the system of vouchers. In the first wave, the number of submitted privatization projects per firm averaged 3.8; for some firms the number of submitted projects was in excess of twenty.

Of the total number of 3,100 firms that entered the first wave, 1,491 were privatized either entirely or in part through the voucher method. ${ }^{3}$ The book value of shares allocated for the voucher privatization scheme in the first wave was 300 billion crowns (about $\$ 11$ billion)." The voucher scheme consisted of the following procedure: each adult Czechoslovak citizen who was a permanent resident of Czechoslovakia was entitled to purchase a voucher book with 1,000 investment "points" for 1,000 crowns (slightly less than one-third of the average monthly wage). 8.57 million adults (i.e., most of the eligible individuals) purchased the voucher books, thus making the average accounting value of assets per voucher book 35,000 crowns. The voucher book holders then used the points to bid for those shares of the 1,491 companies that had been allocated for the voucher distribution.

Prior to the start of the first wave, the voucher book holders could allocate part or all of their points to one or several of the 434 privately formed IPFs or they could keep the points in order to bid for enterprise shares directly. As can be seen from Table 1, 72\% of all voucher points were placed with the IPFs, an outcome that signalled the desire of 
the population to diversify risk in a situation of limited and distorted information. ${ }^{5}$ There was a significant concentration of points among the IPFs, with the 13 largest IPFs having received $56 \%$ of all points remitted to the IPFs.

The process of converting points into shares took place in rounds of bidding. In addition to published background data on all firms, in each round the individuals and IPFs knew the administratively set price of a share in each enterprise (denominated in voucher points) and they submitted written bids, using their points. In the first round, which started on May 18 and ended on June 8,1992, the starting price was set uniformly and arbitrarily at 3 shares of each firm for 100 points. At the start the total value of shares (in points) thus exceeded the total number of points.

As can be seen from Table 1, within each round most firms ended up in a situation of either excess supply or excess demand. In those cases where the supply of shares exceeded the demand for shares by individuals and IPFs, the government exchanged shares for points and adjusted the price per share downwards for the next round. In those cases where demand exceeded supply by less than $25 \%$ and a sufficient part of the demand was represented by the IPFs, all shares were exchanged for points according to the following procedure: the shares were first used to satisfy completely the bids of individual voucher holders and the remainder was then rationed to the bidding IPFs. The rationing of the IPFs was proportional to the size of their bid and each IPF had to receive at least $80 \%$ of its bid. In cases where demand for shares exceeded supply by more than $25 \%$ or where IPFs would have been rationed below $80 \%$ of their bids, the points were returned (no transaction took place) and the price of shares was raised by the government for the next round of bidding.

The adjustment of share prices between individual rounds reflected the dilemma faced by high-level government officials who hoped to adjust share prices so as to achieve rapid convergence between demand and supply. An important assumption underlying their thinking about the optimal price adjustment between rounds was that the overall demand for the shares of a given enterprise could be characterized as having a unitary elasticity with an increase (decrease) in a share price between rounds leading to an equiproportionate decrease (increase) in the demand for shares in the next round. This assumption translated into the working hypothesis that one could induce equilibrium between rounds by adjusting prices proportionately to excess demand, since the overall allocation of points (bids) across firms by individuals and IPFs would remain unchanged. In conceptualizing the process, the top decision-makers thus usually talked about the price with which they could equate demand and supply after each round, once the extent of excess demand for the shares of each firm became known. The officials also increased uncertainty by leaving undetermined the number of rounds and according themselves discretionary powers to alter share prices, remove excess demand firms out of the privatization process and suddenly terminate the first wave.

In practice, the officials relied heavily on their own intuition and discretion. For the second round, for instance, no excess demand firms were taken out of the process. Prices were adjusted according to a simple, linearized, ad hoc scheme which included a price floor (10 shares for 100 points) and a price ceiling (1 share for 400 points). Similarly, for the third round the officials used discretion within a simplified censored scheme that took into account the extent of disequilibria in both the first and second round. In this adjustment process the officials reduced drastically to 97 shares per 100 points the share prices of firms that were in a severe and continuous excess supply. Interestingly, despite dramatic shifts of most firms between excess demand and supply, the officials continued to use the concept of unitary elasticity of demand as a working hypothesis throughout the first wave (see, e.g., Krcmar, 1992). 
Between May and December 1992 the voucher privatization process went through five rounds. After the fourth round the government announced that the fifth round would be the final one and used brute force to terminate the process. In line with its hypothesis of unitary elasticity and limited switching of demand across firms, the government exhorted investors who ended up in excess demand in round four to keep their bids in the same companies in round five. The government announced that it would adjust prices so that all investors in these companies would be assured of receiving shares. In contrast, investors allocating vouchers to companies that ended round four in excess supply were told they would receive shares only if these companies avoided excess demand in round five. In Table 1, we present some of the most important summary statistics related to the privatization process.

\subsection{The basic characteristics of the outcome}

As can be seen from Table 1, the percentage of shares sold in the first five rounds was $30 \%, 25.9 \%, 10.8 \%, 12.4 \%$, and $13.7 \%$, respectively. The authorities hence succeeded in selling 56\% of all shares in the first two rounds alone. This was a remarkable achievement but the drastic adjustment of prices between rounds 2 and 3 resulted in few sales in the third round, as many large firms suddenly ended up in a situation of excess demand. Transactions picked up afterwards and after the fifth (terminal) round this number rose to $92.8 \%$ of all shares being sold.

With $7.2 \%$ of shares remaining unallocated after the terminal (fifth) round, the system hence stopped short of complete convergence. The lack of complete convergence was further accentuated by the fact that the number of firms whose shares sold completely (i.e., firms that experienced less than $25 \%$ excess demand and had sufficient presence of IPFs) was only 48 in the first round, 72 in the second round, 51 in the third round, 79 in the fourth round, and 40 in the fifth round. Hence, with $92.8 \%$ of shares transacted after the fifth round, the scheme succeeded in selling completely less than $20 \%$ of firms. The number of firms that ended each round in excess demand was also high: 469 in the first round, 513 in the second round, 508 in the third round, 369 in the fourth round, and 157 in the fifth round.

Yet, from the practical policy standpoint the extent of convergence was remarkable. Not only were almost $93 \%$ of all shares sold, but only $3.5 \%$ of individuals' and $0.3 \%$ of IPFs' vouchers remained unallocated after the fifth round. The success of the scheme was also underscored by the fact that participation of citizens and IPFs in each round was massive, covering $92 \%$ of all voucher holders in the first round, $88 \%$ in the second round, $93 \%$ in the third round, $88.5 \%$ in the fourth round, and $90.3 \%$ in the fifth round.

When broken down according to individuals $v s$. IPFs (Table 1), the participation by the IPFs is found to have been significantly higher than that of individuals. Measured in terms of the percentage of demand converted into shares, one observes that individuals succeeded in converting $32 \%, 48.9 \%, 8.5 \%, 37.5 \%$, and $83.3 \%$ of their bids into shares in the first, second, third, fourth, and fifth round respectively; IPFs succeeded in converting $40 \%, 54.7 \%, 16 \%, 31.9 \%$, and $90.5 \%$ in these rounds, respectively. The IPFs hence rushed and converted a larger fraction of their points into shares in the early rounds than did individuals. In four out of the five rounds the IPFs also succeeded in realizing a larger proportion of their demand than the individuals, thus presumably buying more proportionately into excess supply firms. The individual investors thus appear to have been less risk averse than the funds and, since prices declined on average after the second round and dramatically so after the third round (see Table 1), the more patient individuals benefited. 
In the rest of the paper we analyse this process of large-scale change in ownership in greater detail.

\section{The data used for empirical work}

The data set used in our empirical investigation comes from the Center for Voucher Privatization of the Czechoslovak Ministry of Finance. It contains official information about each firm that was publicly available to the citizens and IPFs. The data, the summary statistics of which are provided in Appendix Table A1, provide financial and production information about each enterprise, the starting and evolving information about the share prices of each firm during the five rounds of bidding, the value of bids (demand) and actual transactions made by the individual voucher holders as a group and IPFs as a group with respect to each firm in each round.

All the data are available separately for the Czech and Slovak Republics. While individual citizens and IPFs were not constrained geographically in placing their bids, the expected partition of Czechoslovakia and the potentially different future performance of firms in the two republics may have brought about asymmetric demand for shares. The data set permits us to carry out our analysis separately for the Czech and Slovak republics and test this hypothesis. We are also able to test whether the government authorities used the same rule for adjusting prices in the two Republics.

\section{The empirical framework}

An empirical investigation of the determinants of the bidding (demand) behaviour of individual investors and IPFs, as well as the price-setting behaviour of the authorities, is complicated by the lack of a well-established theoretical framework in this area. The problem with applying standard theory stems from the fact that the scheme was highly unusual, the behaviour of all agents was very strategic, and the authorities intentionally raised uncertainty about the rules of the game and their own future moves. The authorities at times also acted highly unpredictably (e.g., in setting prices for round 3 ) and towards the end of the process the behaviour of all agents was in many respects affected by the imminent partition of Czechoslovakia.

In the absence of a tight theoretical framework, our goal in this paper is to generate stylized facts about the main behavioural patterns during the privatization rounds and thus provide a base for future theoretical modelling and policy work. Our empirical specifications are hence loosely guided by standard price theory concepts, game theory notions of strategic interaction and institutional features. The specifications are intentionally flexible so as to permit the data to show up systematic behavioural features.

The empirical model consists of a set of quantity and price regressions. The quantity regressions relate the individual investors' and the IPFs' demand for shares in each firm to a set of firm- and industry-specific background variables which are invariant over the rounds of bidding and a set of variables whose values vary across firms and over the rounds. The regressors are the principal variables that one would expect to influence demand for shares under traditional demand theory as well as in most game theory frameworks, given the available information and the institutional framework. Most regressors are time-invariant, capturing the background situation of each enterprise. These regressors cover financial, sectoral and structural aspects of the firm's performance. The values of three variables - the supply (availability) of shares of each enterprise for the 
upcoming round, the share price set by the authorities for the upcoming round and the ratio of demand/supply (i.e., excess demand) for shares in the previous round - change over time during the rounds. The lagged excess demand was naturally excluded from the first round regressions, as was the share price variable, since all prices were identical at the start. Unless otherwise noted, all price and value regressors take on 1991 values.

The bidding behaviour of IPFs and individuals may be expected to differ for a number of reasons. First, because of their size and expertise, the IPFs are likely to have invested much more heavily into information gathering about firms than individual investors. Uniike individual investors, the IPFs could also hope to assemble sufficiently large packages of shares in specific firms to influence the behaviour of management. For these reasons the IPFs may be expected to concentrate their bids on specific firms and be willing to place these bids at a higher price than individuals. The prediction on the speed with which individuals vs. IPFs will try to convert points into shares is unclear. Individuals may be expected to be more risk averse and hence rush more with the conversion of points into shares. The IPFs on the other hand had to convert large numbers of points and they were rationed in cases of mild excess demand. Finally, because of their size, the IPFs could be expected to bid for shares of firms where a large number of shares was still available. For these and other reasons, we ran the quantity regressions separately for the demand (bids) of individuals and IPFs and we tested the relevant cross-equation restrictions.

Since observed demand is non-negative, the dependent variable is censored on the left. We therefore used the one limit Tobit method for estimating parameters of the demand equations. The residuals displayed heteroscedasticity and the regressions were hence adjusted for heteroscedasticity, using the logarithm of the squared deviations from the mean of the supply of shares, share price and the ratio of share demand to share supply as regressors in the heteroscedasticity adjustment process. Separate runs were carried out and cross equation restrictions were tested for the demand of individuals and IPFs across the two Republics as well as for the stability of coefficients across rounds.

The price regressions relate the share prices set by the authorities for the next round to a set of variables that were used by the authorities to determine the price adjustment. As we indicated in Section 2, the Czechoslovak authorities imposed well-defined limits on the minimum and maximum prices in each round and these limits were also clearly identifiable in the raw data. As a result, in estimating the price equations we used a two limit Tobit with an adjustment for heteroscedasticity. The regressors used in the heteroscedasticity adjustment were the logarithm of the squared deviations from the mean of the supply of shares and the ratio of share demand to share supply.

In order to ensure stability of the heteroscedasticity-Tobit estimator, all estimations were carried out using an iterative maximum likelihood rather than a generalized least squares method in cases where no censoring occurred. In the censored cases, the maximum likelihood method was used. The computations were carried out using the LIMDEP package and several starting values were used for each estimation in order to check that the maximum is a global one.

Since there is no standard way to calculate $\mathrm{R}^{2}$ or other goodness of fit measures in the Tobit framework, in the regression results reported in this paper we calculate quasi$R^{2} s$ as follows. Within the OLS framework the standard F-test of all coefficients except the intercept being zero can be written in terms of $R^{2}$ as: 


$$
F=\frac{R^{2} /(k-1)}{\left(1-R^{2}\right) /(N-k)}
$$

where $\mathrm{N}$ is the number of observations and $\mathbf{k}$ the number of parameters. Upon rearranging,

$$
R^{2}=\frac{F(k-1)}{N-k+F(k-1)}
$$

Now the Wald statistic $W$ is asymptotically distributed as $\chi_{k-1}^{2}$ and $F_{k-1, N-1}$ has an asymptotic distribution as $\left.\left[x_{k-1}^{2} /(k-1)\right] / \chi_{N-k}^{2} /(N-k)\right]$. Since $x_{N-k}^{2} /(N-k)$ goes asymptotically to unity as $\mathrm{N}$ grows, it follows that:

$$
\lim _{N \rightarrow \infty} F=\frac{W}{k-1}
$$

Combining equations (1) and (2) permits us to express an asymptotic (quasi) $\mathbf{R}^{2}$ as $\bar{R}^{2}$ :

$$
\tilde{R}^{2}=\frac{W}{(N-k+W)}
$$

Intuitively, our $\vec{R}^{2}$ corresponds to the standard $R^{2}$ from an OLS equation with the same $\mathrm{N}$ and $\mathrm{k}$, and achieving the same Wald statistic as we do in our regressions.

\section{The empirical results}

\subsection{Demand for shares equations}

The estimated parameters of the demand for shares equations for the first four rounds of bidding are reported in Tables 2-5, respectively, while the results for the fifth round are contained in Tables 6 and 7. The tables contain separate parameter estimates of the individuals' and IPFs' demand for shares of firms in each of the two republics.

\subsubsection{Round 1}

As can be seen from Table 2, with share prices being set arbitrarily at the same level for all firms, financial indicators guided the demand for shares in the first round. Both individuals and IPFs displayed very high and positive demand elasticities with respect to the profitability (profit/share) of firms in both republics. A similarly rational finding is the significant negative elasticity of demand for shares with respect to the firm's total debt/assets ratio, found in all four regressions. While long-term debt reflected the inherited burden from the previous regime, short-term debt in part proxies for the willingness of the financial institutions to lend to the firm. The short-term debt variable in fact displayed positive coefficients in the first round, with three out of four being statistically significant.

The remaining variables displayed less uniform patterns. The size of the firm, proxied by a cubic function of assets, was valued by individual investors but disliked by the IPFs. The extent to which a part of the enterprise's shares was being sold to a foreign (western) 
company was seen as a positive signal by individuals and funds with respect to the Czech enterprises. The coefficients were insignificant with respect to Slovak firms, but this was in large part given by the lack of foreign capital in Slovakia. The percentage of shares being sold to a private Czechoslovak individual or group had a positive effect on the IPFs' demand for shares of the Czech firms but a negative effect on the demand of individuals. The variable had insignificant effects on the demand for shares of the Slovak firms. The change in profits between 1990 and 1991, reflecting the change in enterprise profitability as the country moved from the period of price controls and subsidies to the new era of free prices and limited or no subsidies, had a positive effect on the demand for shares in the Czech Republic and a negative one in Slovakia. The availability (supply) of shares, proxying the probability with which one would succeed in converting points into shares rather than ending up in excess demand, had a strong positive effect on demand for Czech shares by both individuals and funds. In the case of Slovak firms, the coefficient was insignificant for individuals and significantly negative for funds. Since many large Slovak firms allocated $97 \%$ of shares into the voucher scheme, it is possible that the negative coefficient on the number of shares variable reflected the poor quality of some of the large Slovak firms that were included in the voucher scheme. Nonetheless, in comparing the regressions for the Czech and Slovak enterprises it appears that the behaviour of investors vis- $\vec{d}$-vis the Slovak firms was not guided as much by traditional economic criteria as it was vis-d-vis the Czech firms.

The coefficients on the sectoral dummies in Table 2 indicate that, while the funds and individuals displayed some preference for firms in light industry and services, these sectoral preferences were not very strong, ceteris paribus. Similarly, coefficients on a variable measuring the distance of the company from the German or Austrian border and a dummy variable for Prague, which we included in other specifications, were generally insignificant or lacked a clear-cut pattern.

\subsubsection{Round 2}

In the second round the investors faced adjusted prices and had information about the extent of excess demand or supply for the shares of individual companies in round 1 . The question that naturally arises is whether these variables had a significant effect on demand in round 2 . As can be seen from Table 3 , in round 2 the elasticity of demand with respect to own share price was negative in all four regressions, but only in the case of individuals' demand for the shares of Czech companies was it statistically significant. ${ }^{6}$ Similarly, the extent of excess demand (demand/supply) in the previous round did not seem to divert investors' demand to other companies. In fact, this "lethargy" seems to have been precisely the impetus for the "overreaction" of the authorities in adjusting prices for round 3 .

The adjustment of prices and the information about excess demand did, however, reduce the importance of the background financial variables. The profit/share and shortterm debt coefficients in Table 3 remain positive, but are statistically significant only in the case of the IPFs. Moreover, the total indebtedness variable retained its significantly negative coefficient only in the case of IPFs' demand for Czech enterprise shares.

Starting with round 2, both the IPFs and individuals shifted their demand toward larger firms (as measured by assets), ceteris paribus. Pre-purchase of a part of the firm by foreign or domestic investors stopped influencing demand, while the change in profitability between 1990 and 1991 had a uniformly positive effect. With the exception of the IPF demand for Slovak enterprises, the supply of shares started to have a strong positive effect on demand. Sectoral preferences were limited and tended toward the light industry in the Czech Republic. 


\subsubsection{Round 3}

The authorities adjusted prices dramatically between the second and third round and the own price elasticities of demand became significantly negative in the third round, as expected, with respect to the Czech firms (Table 4). In Slovakia, the price elasticities were also negative but statistically insignificant. The effect of the demand/supply ratio in round 2 on demand in round 3 was negative and statistically significant in all four regressions. Both the IPFs and individuals hence started shifting from excessively oversubscribed companies to those characterized by a lower demand/supply ratio.

With more than $55 \%$ of all shares having been sold and the number of remaining rounds being uncertain after the second round, individual as well as institutional investors clearly became concerned about their ability to convert points into sharcs. The availability (supply) of shares became an important determinant of demand of the IPFs and individuals in the third round, with the estimated elasticities on the supply of shares variable being positive and significant in all four regressions in Table 4.

In contrast, with the exception of firm size (proxied by total assets) and possibly short-term debt, the background indicators ceased having a systematic impact on demand.

\subsubsection{Round 4}

By the time investors placed their bids for shares in the fourth round, a number of developments made a rapid conversion of points into shares an important goal for many individuals and IPFs. First, the split of Czechoslovakia into two separate republics became a certainty and the need for the authorities to terminate the first wave of the voucher process became evidently pressing. Second, the authorities explicitly started exhorting investors to keep their bids unchanged rather than switch away from excess demand firms, implying that the adjustment of prices would be such that excess demand would be eliminated and transactions would take place. Third, over two-thirds of all shares earmarked for voucher privatization had been sold.'

As can be seen from Table 5, the share supply variable registered a highly significant and large positive coefficient, reflecting the desire of the remaining investors to succeed in converting their points into shares. At the same time, the exhortation of the authorities not to shy away from firms in excess demand made the coefficient on the lagged demand/supply variable tum strongly positive and highly significant. The estimated price elasticity remained negative in three of the four regressions, but only in the case of individuals' demand for shares in Czech firms was the coefficient statistically significant and negative. Investors hence started to be guided less by price considerations and more by the probability of obtaining shares. The time invariant background variables displayed no systematic pattern.

The results from the first four rounds hence show quite a rational evolution in the determinants of the demand for shares. With prices uniformly set and the pattern of demand unknown, the background financial variables were used as the best criteria for bidding in the first round. However, as prices were adjusted to equilibrate demand and supply and general bidding patterns became known, the time varying price, demand/supply and share supply variables assumed importance over the fixed background variables. Finally, as uncertainty over obtaining shares increased and the authorities exhorted investors not to switch away from excess demand firms, the price variable itself became less important.

\subsubsection{Round 5}

After the fourth round, the authorities announced that the fifth round would be the terminal one and they explicitly exhorted investors to place their bids in the same 
companies as in round 4. The officials indicated that they would adjust prices before the last round so as to eliminate excess demand from round 4 and ensure transactions.

In order to check the effect of these announcements, we estimated round 5 regressions separately for companies that ended round 4 in excess supply (Table 6) and those that were in excess demand (Table 7). Lagrange multiplier tests also indicated that coefficient estimates were significantly different across these two sets of equations.

As can be seen from Table 6, the excess supply companies experienced a similar demand pattern for their shares in round 5 as was observed for all firms in round 4 . The coefficient on the supply of shares variable is very large and highly significant. The coefficient on the lagged demand/supply variable is also positive and significant in three out of the four regressions. The share price and, with the exception of short-term debt, the background variables did not display systematic patterns.

The round 5 regressions for companies that ended up round 4 in excess demand are particularly revealing. In order to test if government jawboning and price adjustment based on its unitary elasticity of demand hypothesis had a significant effect, we included the own demand from round 4, adjusted for the relative price change between rounds 4 and 5 , as an explanatory variable in these regressions. As can be seen from Table 7, this variable is highly significant and registers demand elasticity very close to unity in all four regressions. The estimated coefficients of the other explanatory variables display no systematic pattern. The individuals and IPFs thus appear to have heeded the instructions issued by the authorities in that their aggregate demand from round 4, adjusted for the official price change, explains almost perfectly their aggregate demand in round 5.

\subsection{Tests of cross-equation restrictions}

In order to assess whether the estimated parameters of the various demand equations differ between individuals and IPFs within and across the two republics as well as individuals and IPFs over the various rounds, we carried out a battery of Lagrange multiplier tests. With one sole exception we reject at $1 \%$ significance level the hypothesis that regression parameters are equal between individuals and IPFs both within and across republics. Moreover, the tests always rejected the hypothesis of coefficient stability across rounds. The one exception was the difference between IPFs' demand for shares of excess supply Czech and Slovak companies in round 5. In this case one cannot reject the hypothesis that the coefficients in these two regressions are identical at all conventional significance test levels.

\subsection{Dynamic specifications of demand}

The estimates of the determinants of the demand for shares, reported in Tables 2-7, have come from essentially static specifications. Since the results indicate that the time invariant background variables became gradually less important than the time varying variables, the question naturally arises as to whether the behaviour of individual investors and IPFs displayed systematic dynamic effects. In order to explore this hypothesis, we estimated a set of linear demand equations with lagged dependent and independent variables for rounds $2-5 .^{9}$ In the case of round 2 , where only one lag is possible, we also included the usual background variables in the regression. The results of these regressions, which may be obtained from the authors upon request, indicate that the lagged variables are by and large significant and they diminish the importance of the background variables in comparison with the static model. In accordance with expectations, in most cases the coefficients on current price displayed negative values. The time varying variables hence display dynamic behaviour and the regressions also show a significant degree of persistence in the dependent variable. In addition, we 
allowed for cross effects from lagged demand of IPFs to individuals' current demand and vice versa. This effect was often significant, thus indicating that individual investors and IPFs were influenced by one anothers' past demand.

\subsection{Price adjustment equations}

The price-setting behaviour of the authorities between individual rounds of bidding represented the centralized part of the privatization procedure. Since the originally contemplated complex scheme of price adjustment was greatly simplified when prices actually had to be adjusted between rounds, we used a simple yet flexible specification to approximate the price-setting process. The specification is loglinear and makes the price set for the next round a function of the (remaining) supply of shares and a third order polynomial in the optimal price that would equilibrate the supply and demand for shares under the assumption of unitary price elasticity of demand. This optimal price is given by the price in the preceding round, multiplied by the ratio of demand to supply from the preceding round. For price adjustments in the second and higher rounds, we also included the share price from the preceding round as an explanatory variable. The estimation method is a two-sided censored data Tobit with heteroscedasticity. The explanatory variables used in the heteroscedasticity adjustment are the mean square deviation of the supply of shares and the ratio of demand to supply of shares.

The specification turned out to fit the data very precisely. The ordinary least squares estimates that were used as a starting point for the Tobit regressions produced $\mathrm{R}^{2} \mathrm{~s}$ well in excess of $90 \%$ in all runs and the $\tilde{R}^{2}$ s reported in Table 8 are in most cases in the 0.98-0.99 range.

The estimated coefficients in Table 8 are all highly significant and have the expected signs. The coefficient on the price in the previous round is positive and less than unity in all cases except for the round 5 price adjustment for firms in excess demand. As expected, in virtually all the cases one hence observes a degree of persistence in the price-setting process. The coefficients on the supply of (the number of remaining) shares have negative signs and after the first round they are statistically significant. The "optimal price", given by lagged excess demand weighted by lagged price is positive and highly significant in all rounds, thus suggesting that the authorities' concept of unitary elasticity of demand was persistently being applied in adjusting prices across the rounds. The polynomial specification of this variable yields a positive and convex effect on price in both republics after round 1 and in the Czech Republic also after round 3; it yields a positive and concave effect in both republics after round 2 and for excess demand firms also after round 4. The relationship is essentially linear after the third round in Slovakia and also for excess supply firms after round 4 in both republics.

Using the likelihood values from the Czech and Slovak regressions reported in Table 8 , we carried out likelihood ratio tests of the hypothesis that the price adjustment processes were identical for the Czech and Slovak firms. Although the price adjustment process was supposed to be identical in the two republics, we found that we could reject the hypothesis of equality of the price adjustment coefficients at $1 \%$ significance test level for round 1-2 and 3-4, as well as round 4-5 in the case of excess demand firms. Between rounds 2 and 3 the hypothesis of coefficient equality could not be rejected at the 5\% significance test level and in the case of excess supply firms in round 4-5 the hypothesis could not be rejected at the $1 \%$ level. Our results hence suggest that the authorities frequently applied different criteria for adjusting enterprise share prices in the two republics. 


\section{Conclusions}

The ability to privatize a large part of an economy in a single wave of voucher privatization is unprecedented in history and its feasibility has always been disputed. The Czechoslovak government, totally inexperienced in privatization and market transactions in general, has proved that this task can be done.

An assessment of the scheme and its implementation naturally depends on the evaluation criteria one selects. If the principal goal of a voucher scheme is to sell quickly an overwhelming majority of shares to massively participating individuals and funds, the Czechoslovak scheme must clearly be deemed a success. It sold almost $93 \%$ of all shares in five rounds of bidding and the participation of citizens and institutions in the bidding process was massive, resulting in fewer than $2 \%$ of voucher points not being converted into shares. In contrast, if complete convergence to a market clearing outcome, with most firms selling all shares, is the objective, the scheme is a failure. Less than $20 \%$ of the participating firms sold all their shares after the five rounds and the authorities had to resort to exhortation and finally brute force to terminate the process in round 5 .

From the standpoint of public policy, the former criterion is clearly the more important one and the Czechoslovak example, however inelegant, demonstrates that transferring state ownership of a large number of firms to citizens at large is feasible. The important question that immediately arises is whether the massive transfer of property rights will rapidly engender a superior economic performance in these firms. At present, it is too early even to make conjectures on this point.

Our analysis of the patterns of demand for the shares of the 1,491 firms reveals quite rational behaviour on the part of the millions of individuals and the 434 investment privatization (mutual) funds. First, faced with extreme uncertainty, individual investors voluntarily placed $72 \%$ of their voucher points into the (partially diversified) investment privatization funds. Second, when share prices were set at the same level for all firms in the first round of bidding, individual as well as institutional investors used background financial information about enterprises as a guide for placing their bids. Finally, as the authorities adjusted prices in response to the extent of excess demand, pattems of demand became apparent and the supply of shares shrank over time, these time varying indicators replaced the fixed background indicators as the principal determinants of demand.

The funds turned out to have a lower option value of waiting than individual investors and they converted a larger share of points into shares at higher prices in the earlier rounds. Contrary to the conjectures of some observers, one could detect only weak sectoral preference in demand, ceteris paribus. The dynamic specifications of the demand equations confirm that lagged variables played a significant part and that the supply (availability) of shares, share prices and lagged demand were the principal factors determining demand in a given round.

While the government officials prepared an elaborate scheme for adjusting share prices between rounds, in practice they relied heavily on simple rules and ad hoc approximations. Their public statements as well as our discussions with them revealed that they assumed that the investors' demand for shares of a given enterprise had approximately unitary price elasticity. This behavioural assumption was reflected in the enormous adjustment of prices after the second round, a step which underestimated the response of investors and resulted in an excess demand situation for many firms. Incorporating this behavioural feature permitted us to capture very precisely the official price-setting process with a simple equation. Finally, our tests indicate that the pricesetting behaviour was not identical across the two republics and that it varied over the individual rounds of bidding. 


\section{Endnotes}

1. For earlier discussions of various aspects of the scheme see Kyn (1992), Mejstrik and Burger (1992), Aggarwal and Mejstrik (1992), Krcmar (1992), and Kotrba and Svejnar (1994). For a broader discussion of privatization in Central and East Europe see Frydman and Rapaczynski (1993).

2. By June 1992 the government, for instance, auctioned off about 27,000 units and returned a similar number to previous owners through a process of property restitution. The Czechoslovak government also estimated that by mid-1992 it had auctioned off about two-thirds of all the units that were scheduled to be privatized within the small-scale privatization process. By June 1992 the proceeds from the small-scale privatization amounted to about 35 billion crowns (about $\$ 1.2$ billion). In comparison, the amount of foreign investment for 1991 was about $\$ 650$ million. The details of this scheme may be found, for instance, in Kotrba and Svejnar (1994).

3. Enterprises that were privatized entirely through the voucher method allocated $97 \%$ of their shares for vouchers. Three per cent of shares were kept by the government for potential restitution claims.

4. This amount greatly exceeds the $\$ 1.6$ billion in total foreign direct investment that entered Czechoslovakia between 1989 and 1992. Needless to say, however, the book (accounting) value of assets may differ dramatically from the market valuation. Oldrich Kyn's (1992) detailed calculations, for instance, estimate the expected market value of a voucher book at 14,000 crowns only.

5. It is also worth noting that citizens of the Czech Republic placed over $99 \%$ of their points into Czech IPFs, while citizens of the Slovak Republic placed slightly less than $90 \%$ in Slovak IPFs. The nationality of the fund refers to the republic in which it is registered and not necessarily the republic in which it invests its voucher points.

6. This finding is consistent with the popular hypothesis that the IPFs were interested in obtaining shares in particular companies "at any cost".

7. It should be noted that the composition of the bidding individuals and IPFs also changed dramatically, with the remaining players being less risk averse than the earlier group.

8. The results of all these tests may be obtained from the authors upon request.

9. See, e.g.,-Hendry and Mizon (1978) and Estrin and Svejnar (1992).

\section{References}

Aggarwal, Raj and Michal Mejstrik (1992), "Privatization and Capital Market Development in Eastern Europe: Lessons from the Czechoslovak Experience", Working Paper No. 14, CERGE, Charles University, Prague, September.

Estrin, Saul and Jan Svejnar (1992), "Wage Determination in Labour Managed Firms Under Market-Oriented Reforms: Estimates of Static and Dynamic Models", Working Paper No. 23, CERGE, Charles University, Prague, November 1992 (forthcoming in Journal of Comparative Economics.

Frydman, Roman and Andrzej Rapaczynski (1993), "Insiders and the State: Overview of Responses to Agency Problems in East European Privatization", Economics of Transition, Vol.1(1), pp.39-60. 
Hendry, David and Graham Mizon (1978), "Serial Correlation as a Convenient Simplification, Not a Nuisance", The Economic Journal, No.88, pp.549-63.

Kotrba, Josef and Jan Svejnar (1994), "The Privatization Process in the Czech and Slovak Republics", forthcoming in Nomisma.

Krcmar, Milan (1992), "Voucher Privatization", The Tenth CERGE Lecture on Practical Aspects of Privatization, CERGE, Charles University, Prague, August.

Kyn, Oldrich (1992), "The Market with Vouchers and Investment Funds", The Fifth CERGE Lecture on Practical Aspects of Privatization, CERGE, Charles University, Prague, February.

Mejstrik, Michal, ed. (1992), Privatization Newsletter of Czechoslovakia, No.1-10, JanNovember 1992.

Mejstrik, Michal and James Burger (1992), "The Czechoslovak Large Privatization", Working Paper No. 10, CERGE, Charles University, Prague, July. 
Table 1. Basic data on the first wave of Czechoslovak privatization

Czach Republic Slorak Republic

Total

1. No. of state enterprises

- eligible for privatization

- entering the first wave

- entering the voucher scheme in the first wave

2. Book value of shares allocated for voucher in wave 1 (billion crowns)

3. Millions of CS citizens participating in wave 1 (= no. of points $\times 1,000)$

4. (2/3) Average accounting value of assets per participating citizen (crowns)

5. No. of investment privatization funds (IPFs)

6. \% of voucher points with IPFs IPFs

9. \% of voucher scheme shares sold in wave 1

- round 1

- round 2

- round 3

- round 4

- round 5

10. \% of unallocated voucher points of individuals after

- round 1

- round 2

- round 3

- round 4

- round 5

11. \% of unallocated voucher points of IPFs after

- round 1

- round 2

- round 3

- round 4

- round 5

12. $\%$ of available points used in bidding
- round 1
- round 2
- round 3
- round 4
- round 5

$4,400^{*}$

2,210

$99 \%$

$10 \%$

212.5

2.58

$900^{\circ}$

$6,000^{*}$

3,100 *

988

503

1,491

5.98

35,535

33,682

35,000

434

70.5

$72 \%$

$1 \%$

$100 \%$

$90 \%$

$100 \%$

$21 \%$
$18.1 \%$
$7 \%$
$8.5 \%$
$8.1 \%$

n.a.

$73 \%$

$37.5 \%$

$23.75 \%$

$13.8 \%$

$3.5 \%$

$61.3 \%$

$18.3 \%$

$7.4 \%$

$3.8 \%$

n.a.

$64 \%$

$25.3 \%$

$13.3 \%$

$7.2 \%$

n.a.

$61 \%$

$20.2 \%$

$9.0 \%$

$4.7 \%$

$0.3 \%$ 
Crech Republic Slovak Repablic

Total

13. \% of available points used in bidding by individuals

- round 1

- round 2

- round 3

- round 4

- round 5

$\begin{array}{rrr}85 \% & 82 \% & 84 \% \\ 79.2 \% & 74.5 \% & 78.3 \% \\ 85.5 \% & 80.8 \% & 84.1 \% \\ 78.0 \% & 76.5 \% & 77.6 \% \\ 86.4 \% & 72.7 \% & 81.8 \%\end{array}$

14. \% of available points used in bidding by IPFs

- round 1

- round 2

- round 3

- round 4

- round 5

$94 \%$

$96.4 \%$

$98.8 \%$

$100.0 \%$

$100.0 \%$

15. \% of shares requested by individuals that were allocated

- round 1

- round 2

- round 3

- round 4

- round 5

16. \% of shares requested by IPFs that were allocated

- round 1

- round 2

- round 3

- round 4

- sound 5

17. Average share price in points:

- round 1

- round 2

- round 3

- round 4

- round 5

18. No. of firms that sold all shares

- round 1

- round 2

- round 3

- round 4

- round 5

19. No. of firms in excess demand

- round 1

- round 2

- round 3

- round 4

- round 5

20. No. of firms in excess supply

- round 1

- round 2

- round 3

- round 4

- round 5
$27 \%$

$47.2 \%$

$7.9 \%$

$39.6 \%$

$84.8 \%$

$41 \%$

$55.8 \%$

$16.6 \%$

$35.6 \%$

$91.8 \%$

33.33

$54^{*}$

39.22

15.08

15.13
$98 \%$

$82.1 \%$

$100.0 \%$

$100.0 \%$

$100.0 \%$
$95 \%$

$92.4 \%$

$99.2 \%$

$100.0 \%$

$100.0 \%$

$9.12-12.69$
-112

$\begin{array}{lll}30 & 18 & 48\end{array}$

$\begin{array}{lll}55 & 17 & 72\end{array}$

$24 \quad 27 \quad 51$

$\begin{array}{lll}57 & 22 & 79\end{array}$

$26 \quad 14 \quad 40$

$\begin{array}{lll}350 & 119 & 469\end{array}$

$342 \quad 171 \quad 513$

$362 \quad 145 \quad 508$

$239 \quad 130 \quad 369$

$\begin{array}{lrr}99 & 58 & 157\end{array}$

-Government estimate

$638 \quad 384 \quad 1022$

$\begin{array}{lll}615 & 314 & 929\end{array}$

$\begin{array}{lll}515 & 295 & 810\end{array}$

$\begin{array}{lll}580 & 288 & 868\end{array}$

$\begin{array}{lll}719 & 360 & 1079\end{array}$

Source: Czechoslovak Federal Ministry of Finance. 
Table 2. Demand for shares in the first round - censored data Tobit model with heteroscedasticity

(coefficients are elasticities evaluated at variable means; values in parentheses are standard errors)

\begin{tabular}{|c|c|c|c|c|}
\hline & \multicolumn{2}{|c|}{ Crech enterprises } & \multicolumn{2}{|c|}{ Slovak enterprises } \\
\hline & Funds & Individuals & Funds & Individuals \\
\hline Constant & $\begin{array}{c}-9.98 \\
(34.80)\end{array}$ & $\begin{array}{c}5.78 \\
(55.04)\end{array}$ & $\begin{array}{c}-4.92 \\
(120.70)\end{array}$ & $\begin{array}{c}-1.61 \\
(54.18)\end{array}$ \\
\hline Profit/share & $\begin{array}{l}24.70^{* *} \\
(1.24)\end{array}$ & $\begin{array}{l}29.16^{\circ *} \\
(3.86)\end{array}$ & $\begin{array}{l}29.21^{* *} \\
(2.51)\end{array}$ & $\begin{array}{l}41.41^{* \bullet} \\
(2.36)\end{array}$ \\
\hline Total debV/assets & $\begin{array}{l}-7.55^{* *} \\
(1.30)\end{array}$ & $\begin{array}{c}-10.61 * * \\
(4.34)\end{array}$ & $\begin{array}{l}-23.56 * * \\
(10.47)\end{array}$ & $\begin{array}{c}-21.31^{* \bullet} \\
(5.63)\end{array}$ \\
\hline Short-term debt & $\begin{array}{l}5.27 * * \\
(0.59)\end{array}$ & $\begin{array}{l}3.14^{*} \\
(1.75)\end{array}$ & $\begin{array}{l}6.20^{* *} \\
(1.46)\end{array}$ & $\begin{array}{c}2.24 \\
(1.49)\end{array}$ \\
\hline Total assets & $\begin{array}{l}-5.83^{*} \\
(3.03)\end{array}$ & $\begin{array}{l}35.05^{* *} \\
(7.32)\end{array}$ & $\begin{array}{c}107.56^{* *} \\
(3.25)\end{array}$ & $\begin{array}{l}35.81 * * \\
(2.99)\end{array}$ \\
\hline (Total assets) $^{3}$ & $\begin{array}{l}-0.76 \\
(2.46)\end{array}$ & $\begin{array}{l}-6.59 \\
(9.19)\end{array}$ & $\begin{array}{c}-13.74^{* *} \\
(0.86)\end{array}$ & $\begin{array}{l}3.12^{* *} \\
(0.81)\end{array}$ \\
\hline \% foreign ownership & $\begin{array}{l}3.69^{*} \\
(0.69)\end{array}$ & $\begin{array}{l}8.28^{* *} \\
(1.01)\end{array}$ & $\begin{array}{l}-0.022 \\
(2.74)\end{array}$ & $\begin{array}{c}0.31 \\
(2.49)\end{array}$ \\
\hline $\begin{array}{l}\text { \% Czechoslovak } \\
\text { ownership }\end{array}$ & $\begin{array}{l}2.63^{* *} \\
(1.37)\end{array}$ & $\begin{array}{l}-4.85^{\circ *} \\
(2.41)\end{array}$ & $\begin{array}{l}-0.20 \\
(4.23)\end{array}$ & $\begin{array}{c}1.42 \\
(1.81)\end{array}$ \\
\hline$\Delta$ Profit (1991-1990) & $\begin{array}{l}1.78^{* *} \\
(0.13)\end{array}$ & $\begin{array}{c}1.06^{* *} \\
(-0.34)\end{array}$ & $\begin{array}{l}-6.37^{* 0} \\
(-0.55)\end{array}$ & $\begin{array}{l}-23.03 * * \\
(-0.35)\end{array}$ \\
\hline Supply of shares & $\begin{array}{l}79.01 * * \\
(3.81)\end{array}$ & $\begin{array}{l}24.77^{* *} \\
(9.65)\end{array}$ & $\begin{array}{c}-25.52^{* *} \\
(3.53)\end{array}$ & $\begin{array}{c}3.26 \\
(3.16)\end{array}$ \\
\hline \multicolumn{5}{|l|}{ Sectoral dummies: } \\
\hline Agriculture & $\begin{array}{c}-8.59 \\
(80.24)\end{array}$ & $\begin{array}{c}1.97 \\
(107.50)\end{array}$ & $\begin{array}{c}6.91 \\
(182.69)\end{array}$ & $\begin{array}{c}32.12 \\
(82.17)\end{array}$ \\
\hline Heavy industry & $\begin{array}{l}-19.84 \\
(36.50)\end{array}$ & $\begin{array}{l}-39.71 \\
(71.81)\end{array}$ & $\begin{array}{c}-0.43 \\
(121.00)\end{array}$ & $\begin{array}{c}18.90 \\
(52.49)\end{array}$ \\
\hline Light industry & $\begin{array}{c}66.84^{*} \\
(36.11)\end{array}$ & $\begin{array}{c}47.28 \\
(57.39)\end{array}$ & $\begin{array}{c}52.56 \\
(122.05)\end{array}$ & $\begin{array}{c}19.00 \\
(55.36)\end{array}$ \\
\hline Construction & $\begin{array}{c}6.76 \\
(38.25)\end{array}$ & $\begin{array}{c}-8.69 \\
(93.41)\end{array}$ & $\begin{array}{c}-0.18 \\
(129.54)\end{array}$ & $\begin{array}{c}-9.08 \\
(66.07)\end{array}$ \\
\hline Services & $\begin{array}{l}76.48^{\circ *} \\
(36.97)\end{array}$ & $\begin{array}{l}192.73^{* *} \\
(57.80)\end{array}$ & $\begin{array}{c}86.26 \\
(131.52)\end{array}$ & $\begin{array}{c}46.04 \\
(64.70)\end{array}$ \\
\hline Infrastructure & $\begin{array}{l}-41.01 \\
(55.00)\end{array}$ & $\begin{array}{c}-57.02 \\
(192.20)\end{array}$ & $\begin{array}{c}12.08 \\
(492.99)\end{array}$ & $\begin{array}{c}25.80 \\
(212.20)\end{array}$ \\
\hline N & 988 & 988 & 503 & 503 \\
\hline Nonlimit N & 988 & 988 & 503 & 503 \\
\hline $\mathbf{R}^{2}$ & 0.85 & 0.41 & 0.88 & 0.98 \\
\hline
\end{tabular}

- = Statistically significant at $10 \%$ test level. 
Table 3. Demand for shares in the second round - censored data Tobit model with heteroscedasticity

(coefficients are elasticities evaluated at variable means; values in parentheses are standard errors)

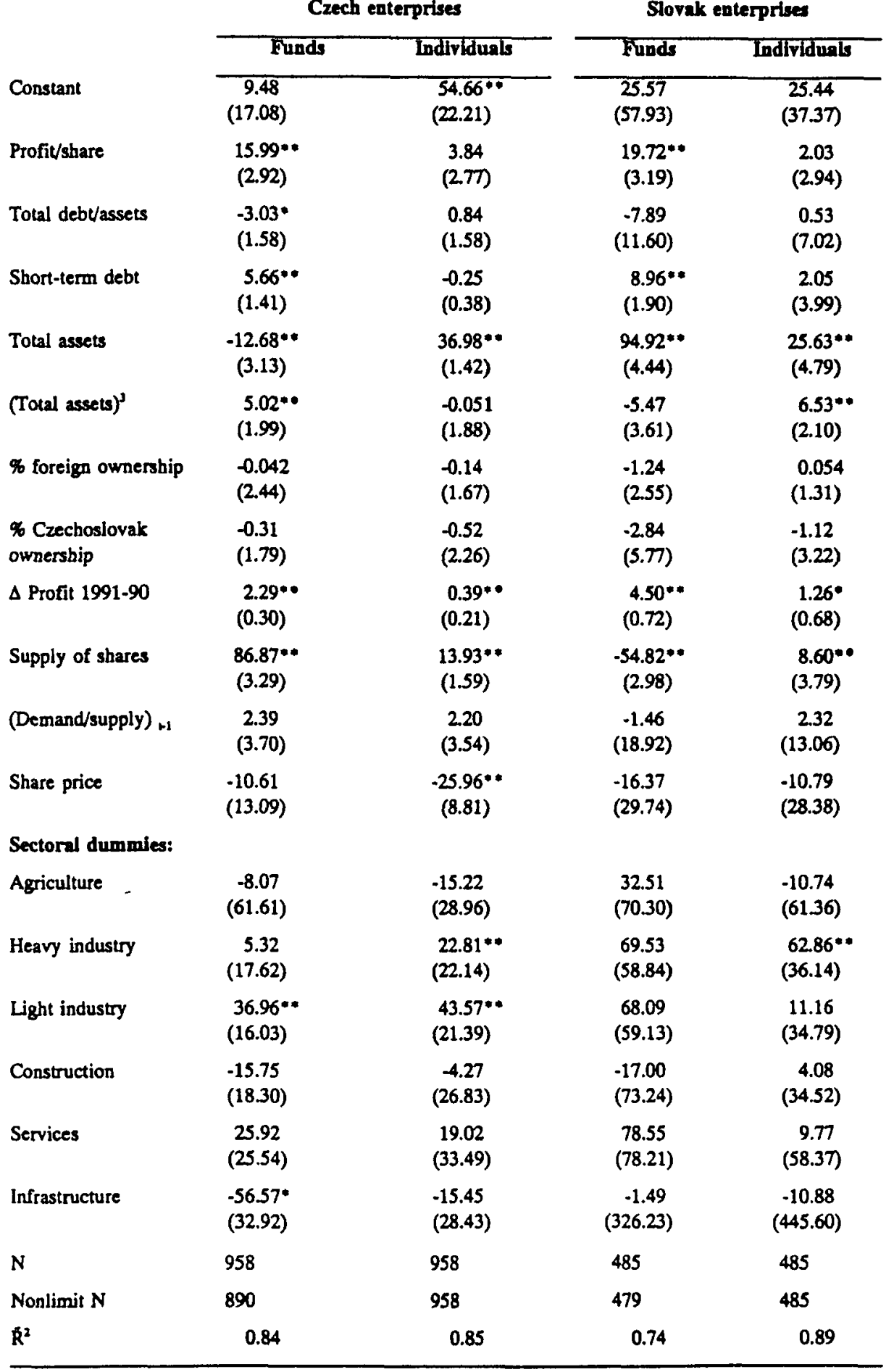

- = Statistically significant at $10 \%$ test level.

- $=$ Statistically significant at $5 \%$ test level. 
Table 4. Demand for shares in the third round - censored data Tobit model with heteroscedasticity (coefficients are elasticities evaluated at variable means; values in parentheses are standard errors)

\begin{tabular}{|c|c|c|c|c|}
\hline & \multicolumn{2}{|c|}{ Czech enterprises } & \multicolumn{2}{|c|}{ Slovak enterprises } \\
\hline & Funds & Individuals & Funds & Individuals \\
\hline Constant & $\begin{array}{c}-1.45 \\
(13.34)\end{array}$ & $\begin{array}{l}24.49 * * \\
(1.70)\end{array}$ & $\begin{array}{c}2.81 \\
(7.47)\end{array}$ & $\begin{array}{c}4.90 \\
(4.98)\end{array}$ \\
\hline Profit/share & $\begin{array}{l}-0.83 \\
(1.64)\end{array}$ & $\begin{array}{l}1.39{ }^{\bullet \bullet} \\
(0.35)\end{array}$ & $\begin{array}{l}-1.26^{* *} \\
(0.47)\end{array}$ & $\begin{array}{l}-0.12 \\
(0.12)\end{array}$ \\
\hline Total debt/assets & $\begin{array}{l}-0.77 \\
(1.66)\end{array}$ & $\begin{array}{c}0.12 \\
(0.78)\end{array}$ & $\begin{array}{l}-0.99 \\
(2.59)\end{array}$ & $\begin{array}{c}0.073 \\
(0.17)\end{array}$ \\
\hline Short-term debt & $\begin{array}{l}-2.51^{* *} \\
(1.18)\end{array}$ & $\begin{array}{l}-0.65 \\
(0.54)\end{array}$ & $\begin{array}{l}-6.21^{* *} \\
(2.00)\end{array}$ & $\begin{array}{l}-1.44^{* *} \\
(0.30)\end{array}$ \\
\hline Total assets & $\begin{array}{l}34.19 \cdot: \\
(2.29)\end{array}$ & $\begin{array}{l}9.61 * * \\
(0.47)\end{array}$ & $\begin{array}{l}7.93^{* \bullet} \\
(2.03)\end{array}$ & $\begin{array}{l}1.33 \% * \\
(0.40)\end{array}$ \\
\hline (Total assets) $^{3}$ & $\begin{array}{l}-5.84 \\
(5.80)\end{array}$ & $\begin{array}{l}-1.14 \\
(3.81)\end{array}$ & $\begin{array}{l}23.09 * * \\
(6.19)\end{array}$ & $\begin{array}{l}33.91^{\circ .} \\
(7.13)\end{array}$ \\
\hline \% foreign ownership & $\begin{array}{l}-0.79 \\
(0.50)\end{array}$ & $\begin{array}{c}0.155^{* *} \\
(0.069)\end{array}$ & $\begin{array}{l}-0.015 \\
(0.46)\end{array}$ & $\begin{array}{c}0.014 \\
(0.15)\end{array}$ \\
\hline $\begin{array}{l}\text { \% Czechoslovak } \\
\text { ownership }\end{array}$ & $\begin{array}{c}0.25 \\
(1.17)\end{array}$ & $\begin{array}{c}0.17 \\
(0.11)\end{array}$ & $\begin{array}{c}1.48 \\
(0.90)\end{array}$ & $\begin{array}{c}0.13 \\
(1.14)\end{array}$ \\
\hline$\triangle$ Profit 1991-1990 & $\begin{array}{l}-0.28 * * \\
(0.096)\end{array}$ & $\begin{array}{c}0.13^{* *} \\
(0.025)\end{array}$ & $\begin{array}{l}2.21^{* *} \\
(0.28)\end{array}$ & $\begin{array}{c}0.086 \\
(0.084)\end{array}$ \\
\hline Share supply & $\begin{array}{l}66.04 * \bullet \\
(2.83)\end{array}$ & $\begin{array}{l}7.92 * * \\
(0.31)\end{array}$ & $\begin{array}{l}67.43^{* *} \\
(3.02)\end{array}$ & $\begin{array}{l}13.08 * 4 \\
(0.94)\end{array}$ \\
\hline (Demand/supply) +1 & $\begin{array}{l}-10.43^{\circ \bullet} \\
(0.89)\end{array}$ & $\begin{array}{l}-2.53^{* *} \\
(0.19)\end{array}$ & $\begin{array}{l}-2.59^{* *} \\
(1.23)\end{array}$ & $\begin{array}{l}-0.44 * * \\
(0.10)\end{array}$ \\
\hline Share price & $\begin{array}{l}-28.27^{\circ *} \\
(6.59)\end{array}$ & $\begin{array}{c}-10.03 * \bullet \\
(1.76)\end{array}$ & $\begin{array}{l}-6.53 \\
(4.26)\end{array}$ & $\begin{array}{l}-3.39 \\
(4.72)\end{array}$ \\
\hline \multicolumn{5}{|l|}{ Sectoral dummies: } \\
\hline Agriculture & $\begin{array}{c}16.64 \\
(26.65)\end{array}$ & $\begin{array}{l}-12.40 * * \\
(1.52)\end{array}$ & $\begin{array}{c}-0.40 \\
(19.93)\end{array}$ & $\begin{array}{r}1.12 \\
(55.27)\end{array}$ \\
\hline Heavy industry & $\begin{array}{c}-5.32 \\
(13.29)\end{array}$ & $\begin{array}{c}-13.87^{\circ \bullet} \\
(1.20)\end{array}$ & $\begin{array}{l}-46.67^{* \bullet} \\
(9.66)\end{array}$ & $\begin{array}{l}-0.31 \\
(1.88)\end{array}$ \\
\hline Light industry & $\begin{array}{c}12.57 \\
(12.91)\end{array}$ & $\begin{array}{l}-9.77^{* * *} \\
(0.85)\end{array}$ & $\begin{array}{c}2.41 \\
(6.92)\end{array}$ & $\begin{array}{l}-0.35 \\
(0.87)\end{array}$ \\
\hline Construction & $\begin{array}{c}8.03 \\
(16.28)\end{array}$ & $\begin{array}{l}-12.85 * * \\
(1.39)\end{array}$ & $\begin{array}{l}-2.79 \\
(7.98)\end{array}$ & $\begin{array}{l}-0.035 \\
(0.86)\end{array}$ \\
\hline Services & $\begin{array}{c}16.64 \\
(16.96)\end{array}$ & $\begin{array}{l}-13.63^{\circ \bullet} \\
(3.17)\end{array}$ & $\begin{array}{c}2.17 \\
(8.52)\end{array}$ & $\begin{array}{l}2.99^{* *} \\
(0.81)\end{array}$ \\
\hline Infrastructure & $\begin{array}{c}-0.39 \\
(21.04)\end{array}$ & $\begin{array}{l}-14.98 \\
(12.88)\end{array}$ & $\begin{array}{l}-33.74 \\
(53.81)\end{array}$ & $\begin{array}{c}-0.77 \\
(110.45)\end{array}$ \\
\hline $\mathbf{N}$ & 902 & 902 & 468 & 468 \\
\hline Nonlimit N & 731 & 901 & 359 & 468 \\
\hline$\dot{\mathbf{R}}^{2}$ & 0.75 & 0.84 & 0.79 & 0.83 \\
\hline
\end{tabular}

- = Statistically significant at $10 \%$ test level.

" =Statistically significant at $S \%$ test level. 
Table 5. Demand for shares in the fourth round - censored data Tobit model with heteroscedasticity

(coefficients are elasticities evaluated at variable means; values in parentheses are standard errors)

Czech enterprises

Slovak enterprises

\begin{tabular}{|c|c|c|c|c|}
\hline \multirow[b]{3}{*}{ Constant } & \multirow{3}{*}{$\begin{array}{l}\text { Funds } \\
-48.63^{\circ *} \\
(21.76)\end{array}$} & \multirow{3}{*}{$\begin{array}{c}\text { Individuals } \\
4.23 \\
(5.62)\end{array}$} & \multirow{3}{*}{$\begin{array}{c}\text { Funds } \\
-29.96^{* 16} \\
(7.79)\end{array}$} & \multirow{3}{*}{$\begin{array}{c}\text { Individuals } \\
-2.61 \\
(3.30)\end{array}$} \\
\hline & & & & \\
\hline & & & & \\
\hline Profit/share & $\begin{array}{c}2.79 \\
(2.32)\end{array}$ & $\begin{array}{r}0.055 \\
(0.82)\end{array}$ & $\begin{array}{l}-0.06 \\
(0.53)\end{array}$ & $\begin{array}{l}-0.86^{* *} \\
(0.17)\end{array}$ \\
\hline Total debu/assets & $\begin{array}{l}-0.40 \\
(3.31)\end{array}$ & $\begin{array}{l}-1.58 * * \\
(0.81)\end{array}$ & $\begin{array}{c}0.99 \\
(2.66)\end{array}$ & $\begin{array}{l}-0.74 \\
(0.69)\end{array}$ \\
\hline Short-term debt & $\begin{array}{l}-1.06 \\
(1.91)\end{array}$ & $\begin{array}{c}0.20 \\
(0.94)\end{array}$ & $\begin{array}{c}-13.84^{* 4} \\
(1.30)\end{array}$ & $\begin{array}{l}3.31 * * \\
(0.94)\end{array}$ \\
\hline Total assets & $\begin{array}{l}6.25^{* *} \\
(2.83)\end{array}$ & $\begin{array}{l}-1.20 \\
(1.29)\end{array}$ & $\begin{array}{l}4.44^{* *} \\
(1.80)\end{array}$ & $\begin{array}{l}-3.33^{\circ *} \\
(0.85)\end{array}$ \\
\hline (Total assets) $^{3}$ & $\begin{array}{c}-3.05 \\
(11.09)\end{array}$ & $\begin{array}{c}0.64 \\
(3.96)\end{array}$ & $\begin{array}{l}21.14 \\
(6.87)\end{array}$ & $\begin{array}{c}3.41 \\
(3.02)\end{array}$ \\
\hline$\%$ foreign ownership & $\begin{array}{l}-0.75 \\
(0.90)\end{array}$ & $\begin{array}{c}0.31 \\
(0.31)\end{array}$ & $\begin{array}{c}0.36 \\
(0.32)\end{array}$ & $\begin{array}{c}0.05 \\
(0.08)\end{array}$ \\
\hline $\begin{array}{l}\text { \% Czechoslovak } \\
\text { ownership }\end{array}$ & $\begin{array}{l}-1.11 \\
(2.39)\end{array}$ & $\begin{array}{l}-0.47 \\
(0.61)\end{array}$ & $\begin{array}{r}0.041 \\
(0.99)\end{array}$ & $\begin{array}{r}0.004 \\
(0.96)\end{array}$ \\
\hline$\Delta$ Profit 1991-1990 & $\begin{array}{c}0.10 \\
(0.16)\end{array}$ & $\begin{array}{l}-0.098 \\
(0.11)\end{array}$ & $\begin{array}{l}-1.86 * * \\
(0.16)\end{array}$ & $\begin{array}{l}-0.31 \bullet * \\
(0.08)\end{array}$ \\
\hline Share supply & $\begin{array}{c}104.16^{*} \\
(2.04)\end{array}$ & $\begin{array}{l}26.16^{* \bullet} \\
(1.33)\end{array}$ & $\begin{array}{l}82.32 * * \\
(2.00)\end{array}$ & $\begin{array}{l}77.39 * * \\
(0.70)\end{array}$ \\
\hline (Demand/supply) $)_{H 1}$ & $\begin{array}{l}34.00^{* *} \\
(5.38)\end{array}$ & $\begin{array}{l}22.24^{* *} \\
(1.43)\end{array}$ & $\begin{array}{l}21.73=\bullet \\
(3.56)\end{array}$ & $\begin{array}{l}3.50^{* *} \\
(1.10)\end{array}$ \\
\hline Share price & $\begin{array}{c}-13.11 \\
(7.43)\end{array}$ & $\begin{array}{c}-16.21^{* *} \\
(3.73)\end{array}$ & $\begin{array}{l}-6.99 \\
(4.81)\end{array}$ & $\begin{array}{c}0.75 \\
(2.40)\end{array}$ \\
\hline \multicolumn{5}{|l|}{ Sectoral dummies: } \\
\hline Agriculture & $\begin{array}{c}5.33 \\
(29.24)\end{array}$ & $\begin{array}{c}4.56 \\
(7.83)\end{array}$ & $\begin{array}{c}6.05 \\
(29.46)\end{array}$ & $\begin{array}{c}2.63 \\
(14.94)\end{array}$ \\
\hline Heavy industry & $\begin{array}{c}-5.16 \\
(21.12)\end{array}$ & $\begin{array}{l}5.84^{*} \\
(2.92)\end{array}$ & $\begin{array}{l}17.93^{* *} \\
(8.65)\end{array}$ & $\begin{array}{l}-0.57 \\
(3.50)\end{array}$ \\
\hline Light industry & $\begin{array}{c}17.87 \\
(20.67)\end{array}$ & $\begin{array}{c}3.78 \\
(3.05)\end{array}$ & $\begin{array}{c}7.85 \\
(6.63)\end{array}$ & $\begin{array}{l}-0.90 \\
(2.39)\end{array}$ \\
\hline Construction & $\begin{array}{c}10.58 \\
(21.70)\end{array}$ & $\begin{array}{c}2.26 \\
(4.37)\end{array}$ & $\begin{array}{c}7.65 \\
(8.58)\end{array}$ & $\begin{array}{l}-0.22 \\
(2.28)\end{array}$ \\
\hline Services & $\begin{array}{c}26.11 \\
(23.11)\end{array}$ & $\begin{array}{l}30.37^{* *} \\
(2.87)\end{array}$ & $\begin{array}{c}10.02 \\
(11.17)\end{array}$ & $\begin{array}{c}2.34 \\
(3.06)\end{array}$ \\
\hline Infrastructure & $\begin{array}{c}17.60 \\
(38.51)\end{array}$ & $\begin{array}{c}8.67 \\
(26.17)\end{array}$ & $\begin{array}{c}4.81 \\
(56.24)\end{array}$ & $\begin{array}{c}-0.10 \\
(39.06)\end{array}$ \\
\hline $\mathbf{N}$ & 877 & 877 & 440 & 440 \\
\hline Nonlimit $\mathbf{N}$ & 729 & 877 & 295 & 440 \\
\hline $\mathbf{R}^{2}$ & 0.99 & 0.62 & 0.99 & 0.99 \\
\hline
\end{tabular}

- = Statistically significant at $10 \%$ test level. 
Table 6. Demand for shares in the fifth round - demand $_{t-1}<$ supply $_{t}$ 1) censored Tobit with heteroscedasticity (coefficients are elasticities evaluated at variable means; values in parentheses are standard errors)

Czech enterprises

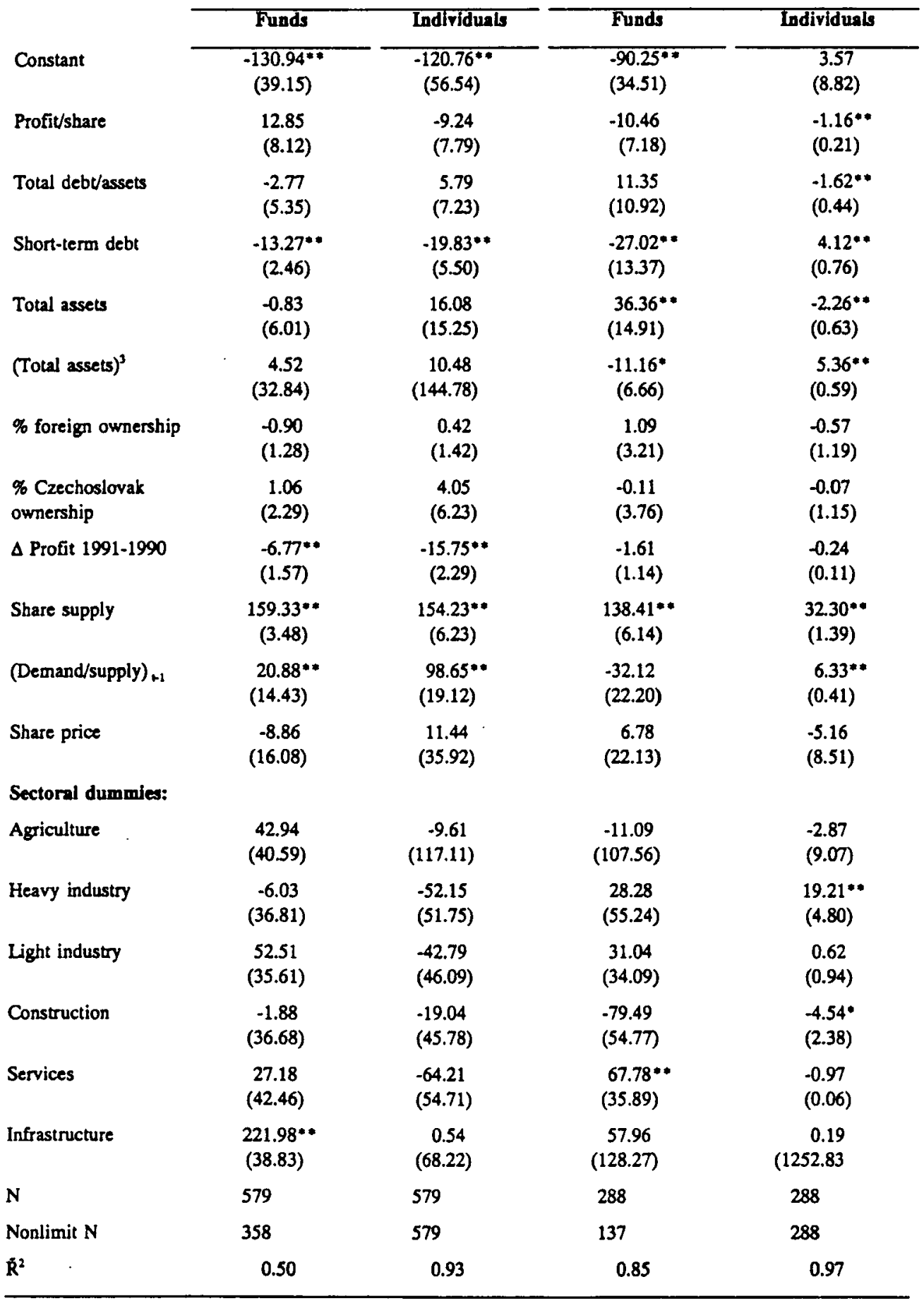

- = Statistically significant at $10 \%$ test level. 
Table 7. Demand for shares in the fifth round - demand $_{t-1}>$ supply $_{t}$ 1) censored Tobit with heteroscedasticity

(coefficients are elasticities evaluated at variable means; values in parentheses are standard errors)

\begin{tabular}{|c|c|c|c|c|}
\hline & \multicolumn{2}{|c|}{ Czech enterprises } & \multicolumn{2}{|c|}{ Shovak enterprises } \\
\hline & Funds & Individuals & Funds & Individuals \\
\hline Constant & $\begin{array}{c}13.92 \\
(38.59)\end{array}$ & $\begin{array}{l}-0.61 \\
(2.63)\end{array}$ & $\begin{array}{c}0.17 \\
(4.20)\end{array}$ & $\begin{array}{l}-1.33 \\
(1.93)\end{array}$ \\
\hline Profit/share & $\begin{array}{l}-1.28 \\
(4.67)\end{array}$ & $\begin{array}{l}-0.72 \\
(0.50)\end{array}$ & $\begin{array}{l}-0.07 \\
(0.44)\end{array}$ & $\begin{array}{l}-0.27 \\
(0.25)\end{array}$ \\
\hline Total debt/assets & $\begin{array}{l}-2.33 \\
(8.83)\end{array}$ & $\begin{array}{l}-0.52 \\
(0.51)\end{array}$ & $\begin{array}{l}-0.33 \\
(2.20)\end{array}$ & $\begin{array}{c}2.44 \\
(1.77)\end{array}$ \\
\hline Short-term debt & $\begin{array}{l}7.27^{* *} \\
(2.58)\end{array}$ & $\begin{array}{l}-1.58^{* *} \\
(0.55)\end{array}$ & $\begin{array}{c}3.93 \\
(4.03)\end{array}$ & $\begin{array}{l}-10.91^{\circ * *} \\
(1.98)\end{array}$ \\
\hline Total assets & $\begin{array}{c}3.81 \\
(4.10)\end{array}$ & $\begin{array}{l}-2.41^{* *} \\
(0.66)\end{array}$ & $\begin{array}{l}-4.71 \\
(4.85)\end{array}$ & $\begin{array}{l}4.78^{*} \\
(2.54)\end{array}$ \\
\hline (Total assets) $^{3}$ & $\begin{array}{l}-2.01^{\bullet} \\
(1.11)\end{array}$ & $\begin{array}{l}1.16^{* *} \\
(0.29)\end{array}$ & $\begin{array}{l}6.90 \\
(7.87)\end{array}$ & $\begin{array}{l}-5.50 \\
(6.83)\end{array}$ \\
\hline $\begin{array}{l}\text { \% foreign } \\
\text { ownership }\end{array}$ & $\begin{array}{c}0.00 \\
(0.87)\end{array}$ & $\begin{array}{l}-0.04 \\
(0.29)\end{array}$ & & \\
\hline $\begin{array}{l}\text { \% Czechoslovak } \\
\text { ownership }\end{array}$ & $\begin{array}{l}-0.21 \\
(1.81)\end{array}$ & $\begin{array}{c}0.15 \\
(0.31)\end{array}$ & $\begin{array}{l}-0.05 \\
(0.16)\end{array}$ & $\begin{array}{c}0.06 \\
(0.08)\end{array}$ \\
\hline$\Delta$ Protit $1991-1990$ & $\begin{array}{l}-0.84 \\
(2.60)\end{array}$ & $\begin{array}{l}-0.31 \\
(0.41)\end{array}$ & $\begin{array}{l}1.75^{* *} \\
(0.44)\end{array}$ & $\begin{array}{l}-1.78 * \bullet \\
(-0.48)\end{array}$ \\
\hline Share supply & $\begin{array}{c}-26.56^{* *} \\
(6.46)\end{array}$ & $\begin{array}{r}2.75^{*} \\
(1.48)\end{array}$ & $\begin{array}{c}-14.64 * * \\
(7.08)\end{array}$ & $\begin{array}{l}9.20 * * \\
(1.82)\end{array}$ \\
\hline (Demand/supply) $)_{s-1}$ & $\begin{array}{l}-6.98 \\
(7.75)\end{array}$ & $\begin{array}{l}-0.78 * * \\
(0.35)\end{array}$ & $\begin{array}{l}-1.08 \\
(2.89)\end{array}$ & $\begin{array}{l}-0.07 \\
(0.87)\end{array}$ \\
\hline Share price & $\begin{array}{l}-6.24 \\
(4.14)\end{array}$ & $\begin{array}{l}0.74 * * \\
(2.22)\end{array}$ & $\begin{array}{c}0.22 \\
(0.48)\end{array}$ & $\begin{array}{c}0.37 \\
(0.74)\end{array}$ \\
\hline $\begin{array}{l}\text { (Fund's demand }{ }_{1-1} \text {. } \\
\left.P_{n-1}\right) / P_{t}\end{array}$ & $\begin{array}{l}119.02^{* *} \\
(6.64)\end{array}$ & & $\begin{array}{c}103.79 * * \\
(6.90)\end{array}$ & \\
\hline $\begin{array}{l}\text { (Individual demand } \\
\left.{ }_{1-1}, P_{t-1}\right) / P_{t}\end{array}$ & & $\begin{array}{c}104.96^{* *} \\
(1.24)\end{array}$ & & $\begin{array}{c}119.54^{* \bullet} \\
(1.57)\end{array}$ \\
\hline Sectoral & & & & \\
\hline Agriculture & $\begin{array}{c}-8.59 \\
(44.58)\end{array}$ & $\begin{array}{l}-0.28 \\
(2.30)\end{array}$ & $\begin{array}{l}-1.22 \\
(4.68)\end{array}$ & $\begin{array}{l}-9.94^{*} \\
(5.99)\end{array}$ \\
\hline Heavy industry & $\begin{array}{l}-13.14 \\
(40.11)\end{array}$ & $\begin{array}{l}-1.93 \\
(1.49)\end{array}$ & $\begin{array}{l}-2.87 \\
(4.75)\end{array}$ & $\begin{array}{l}-2.81 \\
(2.75)\end{array}$ \\
\hline Light industry & $\begin{array}{l}-17.71 \\
(38.27)\end{array}$ & $\begin{array}{l}-2.30 \\
(1.76)\end{array}$ & $\begin{array}{l}-2.70 \\
(5.52)\end{array}$ & $\begin{array}{l}-3.93^{*} \\
(2.28)\end{array}$ \\
\hline Construction & $\begin{array}{c}-3.56 \\
(38.52)\end{array}$ & $\begin{array}{c}0.34 \\
(7.27)\end{array}$ & $\begin{array}{l}-2.11 \\
(7.89)\end{array}$ & $\begin{array}{l}-2.72 \\
(2.25)\end{array}$ \\
\hline Services & $\begin{array}{c}7.99 \\
(50.46)\end{array}$ & $\begin{array}{l}-3.22 \\
(3.09)\end{array}$ & $\begin{array}{c}-4.47 \\
(10.94)\end{array}$ & $\begin{array}{c}-1.32 \\
(17.73)\end{array}$ \\
\hline Infrastructure & $\begin{array}{l}-56.53 \\
(40.74)\end{array}$ & $\begin{array}{c}-5.87 \\
(11.87)\end{array}$ & $\begin{array}{c}1.56 \\
(49.56)\end{array}$ & $\begin{array}{l}-12.71 \\
(58.22)\end{array}$ \\
\hline $\mathbf{N}$ & 239 & 239 & 130 & 130 \\
\hline Nonlimit $\mathbf{N}$ & 220 & 239 & 100 & 130 \\
\hline$\tilde{\mathbf{R}}^{2}$ & 0.97 & $0.99=$ & 0.98 & $0.99 *$ \\
\hline
\end{tabular}

- = Statistically significant at $10 \%$ test level. 
Table 8. Price adjustment variables - censored data Tobit model with heteroscedasticity

(dependent variable $=$ enp; values in parentheses are standard errors)

\begin{tabular}{|c|c|c|c|c|c|c|c|c|c|c|}
\hline & \multicolumn{2}{|c|}{ Round 1-2 } & \multicolumn{2}{|c|}{ Round 2-3 } & \multicolumn{2}{|c|}{ Round 3-4 } & \multicolumn{2}{|c|}{$\begin{array}{l}\text { Round 45 } \\
\text { Demed, > } \\
\text { Supply, }\end{array}$} & \multicolumn{2}{|c|}{$\begin{array}{l}\text { Roond 45 } \\
\text { Demand, < } \\
\text { Supply, }\end{array}$} \\
\hline & Crech & Slovak & Crech & ch Slorak & Czech & h Slovak & Cuech & h Slovak & Cuech & Slovak \\
\hline Constant & $\begin{array}{l}4.36 \\
(0.92)(\end{array}$ & $\begin{array}{l}4.14^{* *} \\
(0.83)\end{array}$ & $\begin{array}{l}4.86^{\circ *} \\
(0.13)\end{array}$ & $\begin{array}{l}4.53^{*} \\
(0.17)\end{array}$ & $\begin{array}{l}2.04^{* *} \\
(0.06)\end{array}$ & $\begin{array}{l}1.65^{* *} \\
(0.08)\end{array}$ & $\begin{array}{r}4.28^{\circ} \\
(0.08)(\end{array}$ & $\begin{array}{l}-4.75^{\circ \bullet} \\
(0.5)\end{array}$ & $\begin{array}{l}2.38 \cdot 4 \\
(0.06)\end{array}$ & $\begin{array}{l}2.39 \cdot 4 \\
(0.10)\end{array}$ \\
\hline In (Sbare price) & & & $\begin{array}{l}0.44^{* *} \\
(0.02)\end{array}$ & $\begin{array}{l}0.46^{* *} \\
(0.03)\end{array}$ & $\begin{array}{c}0.73^{* *} \\
(0.005)\end{array}$ & $\begin{array}{r}0.76^{* *} \\
(0.007)\end{array}$ & $\begin{array}{l}0.15 * \\
(0.02)(\end{array}$ & $\begin{array}{l}0.03 \\
(0.03)\end{array}$ & $\begin{array}{l}0.61^{* \bullet} \\
(0.01)\end{array}$ & $\begin{array}{l}0.59 * \bullet \\
(0.01)\end{array}$ \\
\hline in (Supply), & $\begin{array}{l}-0.004) \\
(0.008)(\end{array}$ & $\begin{array}{l}-0.002 \\
(0.008))\end{array}$ & $\begin{array}{l}-0.19 * \bullet \\
(0.009)\end{array}$ & $\begin{array}{l}-0.16^{* *} \\
(0.012)\end{array}$ & $\begin{array}{l}-0.075 * \bullet \\
(0.005)\end{array}$ & $\begin{array}{l}-0.053^{* \bullet} \\
(0.005)\end{array}$ & $\begin{array}{l}-0.02 * 5 \\
(0.00)(\end{array}$ & $\begin{array}{l}0.02 \\
(0.00)\end{array}$ & $\begin{array}{l}-0.03 * \bullet \\
(0.01)\end{array}$ & $\begin{array}{l}-0.02 \cdot 0 \\
(0.01)\end{array}$ \\
\hline $\begin{array}{l}\text { in (Demand/supply) } \\
P_{b 1} \text {. }\end{array}$ & $\begin{array}{l}1.07 \bullet \bullet \\
(0.012)(C\end{array}$ & $\begin{array}{l}0.94 \% " \\
(0.014)\end{array}$ & $\begin{array}{l}0.63 \bullet \bullet \\
(0.026)\end{array}$ & $\begin{array}{l}0.59 * \bullet \\
(0.039)\end{array}$ & $\begin{array}{c}0.21^{\circ \bullet} \\
(0.019)\end{array}$ & $\begin{array}{l}0.097^{* \bullet} \\
(0.032)\end{array}$ & $\begin{array}{c}0.87 * * \\
(0.03)(\end{array}$ & $\begin{array}{l}0.96 * \bullet \\
(0.04)\end{array}$ & $\begin{array}{l}0.35 \cdots \\
(0.02)\end{array}$ & $\begin{array}{l}0.39 * * \\
(0.06)\end{array}$ \\
\hline $\begin{array}{l}\left.\text { [n (Demand/supply })_{+1}\right]^{2} \text {. } \\
P_{+1}\end{array}$ & $\begin{array}{l}0.19 * * \\
(0.008)(\end{array}$ & $\begin{array}{r}0.16 * \bullet \\
(0.095)\end{array}$ & $\begin{array}{l}-0.13^{* \bullet} \\
(0.011)\end{array}$ & $\begin{array}{l}-0.14^{* *} \\
(0.013)\end{array}$ & $\begin{array}{l}0.042 * \bullet \\
(0.01)\end{array}$ & $\begin{array}{l}-0.005 \\
(0.013)\end{array}$ & $\begin{array}{l}-0.04 * 5 \\
(0.01)(\end{array}$ & $(0.01)$ & $\begin{array}{c}0.00 \\
(0.02)\end{array}$ & $\begin{array}{c}0.02 \\
(0.03)\end{array}$ \\
\hline 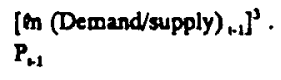 & $\begin{array}{l}0.011^{\bullet * 4} \\
(0.001)(C\end{array}$ & $\begin{array}{l}-0.01^{\circ \bullet} \\
(0.002)\end{array}$ & $\begin{array}{l}-0.027^{\circ *} \cdot- \\
(0.002)\end{array}$ & $\begin{array}{l}-0.025 * * \\
(0.002)\end{array}$ & $\begin{array}{l}0.009 * \bullet \\
(0.001)\end{array}$ & $\begin{array}{c}0.003 \\
(0.002)\end{array}$ & $\begin{array}{l}-0.01 * 9 \\
(0.00)(\end{array}$ & $\begin{array}{l}9.01=0 \\
(0.00)\end{array}$ & $\begin{array}{l}0.00 \\
(0.001)\end{array}$ & $\begin{array}{l}0.00 \\
(0.001)\end{array}$ \\
\hline $\mathbf{N}$ & 958 & 485 & 902 & 468 & 877 & 440 & 239 & 130 & 579 & 288 \\
\hline $\mathbf{R}^{2}$ & 0.98 & 0.99 & 0.92 & 0.95 & 0.98 & 0.99 & 0.99 & 0.99 & 0.99 & 0.99 \\
\hline
\end{tabular}

- Statistically significant at $10 \%$ test level.

- - Statistically sigrificant at 5\% test level. 


\section{Appendix A}

Table A1. Summary statistics of the main variables

\begin{tabular}{|c|c|c|c|c|}
\hline Variable & Mean & Standard derlation & Minlmum & Maximum \\
\hline \multicolumn{5}{|l|}{ Czechoslovaldn round 1} \\
\hline Profit/share & 0.18 & 0.58 & -1.14 & 15.76 \\
\hline \% Total debt/assets & 47.00 & 137.00 & 0.00 & 3163.00 \\
\hline Short-term debt & $4.3 \mathrm{E}+05$ & $5.7 \mathrm{E}+06$ & $-3.7 \mathrm{E}+05$ & $2.2 E+08$ \\
\hline Total assets & $3.1 E+05$ & $1.5 E+07$ & 1117.0 & $4.9 \mathrm{E}+07$ \\
\hline \% Foreign ownership & 1.34 & 8.00 & 0.00 & 80.00 \\
\hline \% Czechoslovak ownership & 3.25 & 12.51 & 0.00 & 84.00 \\
\hline$\Delta$ Profit (1991-1990) & -14636 & $5.7 E+05$ & $-1.3 E+07$ & $1.7 \mathrm{E}+07$ \\
\hline \multicolumn{5}{|l|}{ Sectoral dummies: } \\
\hline Agriculture & 0.075 & 0.26 & 0.00 & 1.00 \\
\hline Heavy industry & 0.24 & 0.43 & 0.00 & 1.00 \\
\hline Light industry & 0.22 & 0.41 & 0.00 & 1.00 \\
\hline Construction & 0.19 & 0.39 & 0.00 & 1.00 \\
\hline Services & 0.099 & 0.30 & 0.00 & 1.00 \\
\hline Infrastructure & 0.029 & 0.17 & 0.00 & 1.00 \\
\hline Supply of shares & $2.0 \mathrm{E}+05$ & $6.0 \mathrm{E}+05$ & 713.0 & $1.5 \mathrm{E}+07$ \\
\hline Share price & 33.33 & 0.0 & 33.33 & 33.33 \\
\hline Equilibrium price & 0.41 & 1.44 & $\begin{array}{l}0.122 \mathrm{E}- \\
02\end{array}$ & 48.47 \\
\hline \multicolumn{5}{|l|}{ Czech round 1} \\
\hline Profit/share & 0.23 & 0.68 & -1.14 & 15.76 \\
\hline$\%$ total debt/assets & 49.00 & 161.00 & 0.00 & 3163.00 \\
\hline Short-term debt & $5.3 E+05$ & $6.9 E+06$ & $-3.7 \varepsilon+05$ & $2.2 \mathrm{E}+08$ \\
\hline Total assets & $3.5 \mathrm{E}+05$ & $1.7 \mathrm{E}+06$ & 2239.00 & $4.9 \mathrm{E}+07$ \\
\hline \% foreign ownership & 1.62 & 8.68 & 0.00 & 75.00 \\
\hline \% Czechoslovak ownership & 3.76 & 13.49 & 0.00 & 84.00 \\
\hline$\Delta$ Profit (1991-1990) & -14881 & $7.0 \mathrm{E}+05$ & $-1.3 \mathrm{E}+07$ & 1.7E+07 \\
\hline \multicolumn{5}{|l|}{ Sectoral dummies: } \\
\hline Agriculture & 0.077 & 0.27 & 0.00 & 1.00 \\
\hline Heavy industry & 0.27 & 0.45 & 0.00 & 1.00 \\
\hline Light industry & 0.21 & 0.41 & 0.00 & 1.00 \\
\hline Construction & 0.17 & 0.37 & 0.00 & 1.00 \\
\hline
\end{tabular}




\begin{tabular}{|c|c|c|c|c|}
\hline Variable & Mean & Standard deviation & Minimum & Maximum \\
\hline Services & 0.11 & 0.31 & 0.00 & 1.00 \\
\hline Infrastructure & 0.037 & 0.19 & 0.00 & 1.00 \\
\hline Supply of shares & $2.2 \mathrm{E}+05$ & $6.1 E+05$ & 2172. & $1.5 E+07$ \\
\hline Share price & 33.33 & 0.0 & 33.33 & 33.33 \\
\hline Equilibrium price & 0.46 & 1.65 & 0.0012 & 48.47 \\
\hline \multicolumn{5}{|l|}{ Slovalda round 1} \\
\hline Profit/share & 0.099 & 0.26 & -1.06 & 2.67 \\
\hline Total debt/assets & 42.00 & 71.00 & 0.00 & 969.00 \\
\hline Short-term debt & $2.2 \mathrm{E}+05$ & $1.0 \mathrm{E}+06$ & -30.00 & $1.7 E+07$ \\
\hline Total assets & $2.3 E+05$ & $9.6 \mathrm{E}+06$ & 1117. & $1.6 E+07$ \\
\hline$\%$ foreign ownership & 0.78 & 6.44 & 0.00 & 80.00 \\
\hline \% Czechoslovak ownership & 2.25 & 10.25 & 0.00 & 83.00 \\
\hline$\Delta$ Profit (1991-1990) & -14156 & $1.1 E+05$ & $-1.8 \mathrm{E}+06$ & $4.2 E+05$ \\
\hline \multicolumn{5}{|l|}{ Sectoral dummies: } \\
\hline Agriculture & 0.072 & 0.26 & 0.00 & 1.00 \\
\hline Heavy industry & 0.17 & 0.38 & 0.00 & 1.00 \\
\hline Light industry & 0.24 & 0.43 & 0.00 & 1.00 \\
\hline Construction & 0.23 & 0.42 & 0.00 & 1.00 \\
\hline Services & 0.074 & 0.26 & 0.00 & 1.00 \\
\hline Infrastructure & 0.012 & 0.11 & 0.00 & 1.00 \\
\hline Supply of shares & $1.7 \mathrm{E}+05$ & $6.0 \mathrm{E}+05$ & 713.0 & $1.2 \mathrm{E}+07$ \\
\hline Share price & 33.33 & 0.0 & 33.33 & 33.33 \\
\hline Equilibrium price & 0.32 & 0.87 & $1.5 \mathrm{E}-01$ & 14.88 \\
\hline \multicolumn{5}{|l|}{ Czechoslovakia round 2} \\
\hline Supply of shares & $1.5 E+05$ & $3.9 E+05$ & 58.09 & $9.2 E+06$ \\
\hline Share price & 38.28 & 49.85 & 10.00 & 400.00 \\
\hline Equilibrium price & 0.40 & 0.96 & $1.1 \mathrm{E}-03$ & 19.31 \\
\hline \multicolumn{5}{|l|}{ Czech round 2} \\
\hline Supply of shares & $1.5 \mathrm{E}+05$ & $3.3 E+05$ & 58.00 & $5.1 E+06$ \\
\hline Share price & 42.16 & 52.56 & 10.00 & 400.00 \\
\hline Equilibrium price & 0.42 & 0.87 & $1.1 \mathrm{E}-03$ & 19.24 \\
\hline \multicolumn{5}{|l|}{ Slovakia round 2} \\
\hline Supply of shares & $1.4 E+05$ & $4.9 \mathrm{E}+05$ & 69.00 & $9.2 \mathrm{E}+06$ \\
\hline
\end{tabular}




\begin{tabular}{|c|c|c|c|c|}
\hline Variable & Mean & Standard deviation & Minimum & Maximum \\
\hline Share price & 30.61 & 43.06 & 10.00 & 400.00 \\
\hline Equilibrium price & 0.36 & 1.12 & $1.1 \mathrm{E}-03$ & 19.31 \\
\hline \multicolumn{5}{|c|}{ Czechoslorakia round 3} \\
\hline Supply of shares & 96443. & $3.2 E+05$ & 10.00 & $6.8 \mathrm{E}+07$ \\
\hline Share price & 55.98 & 94.79 & 1.03 & 800.00 \\
\hline Equilibrium price & 0.30 & 0.76 & 0.00 & 14.19 \\
\hline \multicolumn{5}{|l|}{ Czech round 3} \\
\hline Supply of shares & 94476. & $2.8 \mathrm{E}+05$ & 26.00 & $5.1 \mathrm{E}+06$ \\
\hline Share price & 60.09 & 98.04 & 1.03 & 800.00 \\
\hline Equilibrium price & 0.32 & 0.77 & 0.00 & 14.19 \\
\hline \multicolumn{5}{|l|}{ Slovalda round 3} \\
\hline Supply of shares & $1.0 \mathrm{E}+05$ & $3.8 \mathrm{E}+05$ & 10.00 & $6.8 \mathrm{E}+06$ \\
\hline Share price & 48.07 & 87.75 & 1.03 & 800.00 \\
\hline Equilibrium price & 0.25 & 0.73 & $3.5 \mathrm{E}-03$ & 13.20 \\
\hline \multicolumn{5}{|c|}{ Czechoslovakia round 4} \\
\hline Supply of shares & 75608. & $2.85 E+05$ & 13.0 & $6.75 E+06$ \\
\hline Share price & 60.97 & 112.02 & 1.67 & 1000.0 \\
\hline Equilibrium price & 0.33 & 2.15 & 0.01 & 73.72 \\
\hline \multicolumn{5}{|l|}{ Czech round 4} \\
\hline Supply of shares & 73545. & $2.17 \mathrm{E}+05$ & 26.00 & $3.39 \mathrm{E}+06$ \\
\hline Share price & 64.58 & 119.04 & 1.666 & 1000. \\
\hline Equilibrium price & 0.38 & 2.60 & 0.01 & 73.72 \\
\hline \multicolumn{5}{|l|}{ Slovak round 4} \\
\hline Supply of shares & 79718. & $3.85 E+05$ & 13.00 & $6.75 E+06$ \\
\hline Share price & 53.78 & 96.26 & 1.69 & 800.0 \\
\hline Equilibrium price & 0.24 & 0.62 & 0.01 & 8.95 \\
\hline \multicolumn{5}{|c|}{ Czechoslovakja round 4} \\
\hline Supply of shares & 50566. & $2.54 \mathrm{E}+05$ & 7.00 & $6.75 \mathrm{E}+06$ \\
\hline Share price & 59.65 & 103.10 & 1.67 & 1000 \\
\hline Equilibrium price & 0.34 & 1.35 & 0.01 & 29.23 \\
\hline
\end{tabular}




\begin{tabular}{lcccc}
\hline Varlable & Mean & Standard deviation & Minimum & Maximum \\
\hline Czech round 5 & & & & \\
Supply of shares & 47612. & $1.83 \mathrm{E}+05$ & 7.00 & $3.4 \mathrm{E}+06$ \\
Share price & 62.43 & 106.20 & 1.67 & 1000 \\
Equilibrium price & 0.37 & 1.60 & 0.01 & 29.23 \\
\hline Slovak round 5 & & & & \\
Supply of shares & 56348. & $3.54 \mathrm{E}+05$ & 8.00 & $6.75 \mathrm{E}+06$ \\
Share price & 54.21 & 96.63 & 1.92 & 800.0 \\
Equilibrium price & 0.27 & 0.60 & 0.01 & 6.77 \\
\hline
\end{tabular}

